\title{
Proximate Analysis of Ostrich Meat to Assess the Quality in Chilled and Frozen Condition
}

\author{
R. P. Yadav ${ }^{1 *}$ and A. Mishra ${ }^{2}$ \\ ${ }^{1}$ Himalayan College of Agricultural Sciences \&Technology, Kathmandu, Nepal \\ ${ }^{2}$ Food Research division, Nepal Agricultural Research Council \\ *Corresponding author: rajendravet10@gmail.com
}

\begin{abstract}
Ostrich meat is very popular due to its healthy composition thereby increasing its demand globally. Therefore, one study has been made on quality of ostrich meats of different ages at chilled and frozen conditions by targeting product development. Meat samples from two differently aged, 10- and 14-months ostriches were collected and divided into three parts for each type. One part was analyzed immediately, one part was put in chilling at $4^{\circ} \mathrm{C}$ for 72 hours and next part was put in deep fridge at $-20^{\circ} \mathrm{C}$ for 30 days. Proximate analyses were carried out for moisture (73.98 to $75.22 \%)$, protein (21.08 to $22.46 \%)$, total fat (2.43 to $3.27 \%$ ) and total minerals $(0.83$ to $1.82 \%$ ). There was subsequent decrement in moisture at cold storage practices, at 72 hours chilling by $1 \%$ and one month freezing by $2.3 \%$ and there was no significant (?) difference in water content due to the age of bird. The amount of protein was found increasing at chilling, freezing and ageing? total fat was significantly different due to the age as well as meat storage practices and total ash was in decreasing trend in case of chilling and freezing conditions but found no difference due to the age.
\end{abstract}

Keywords: ostrich meat, proximate analysis, deep fridge, storage, protein, moisture, total fat, mineral.

\section{INTRODUCTION}

Meat consumption in developing countries has been continuously increasing. There are economic, dietary and sensory aspects that make meat processing one of the most valuable mechanisms for adequately supplying animal protein to human populations (Heinz and Hautzinger, 2007). These circumstances coerce into the diversification of meat into variety of meat products. The total annual meat production in Nepal is 288 thousand MT in which buffalo contributes the largest supply (64.1\%) followed by goat (17.46\%), sheep (1.33\%), pig (7.38\%), and poultry (9.61\%) (CBS, 2014/15). From the data of five years, it can be said that production and consumption of poultry meat is in increasing trend in Nepal. 
Introduction Over the last decade there is still observed a growing interest in ostrich farming and husbandry worldwide (Cooper et al., 2008). In Nepal also ostrich farming is in increasing trend just like as livestock and livestock products especially as a source of foods leathers, feathers and eggs. Its meat has been started to retail in meat mart since 2008 in Nepal. Ostrich meat is very popular due to the low level of cholesterol, calories, fat free, high level of iron and proteins, rich of omega 3, 6, and 9 with low saturated fat contents of $0.5 \%$ with rich of taste and easy to prepare. That's why ostrich meat is increasing rapidly and gaining popularity globally among the health-conscious red meat lovers.

Protein levels are high in ostrich meat, of about $28 \%$ in average, and the most frequent amino acid is creatinine (Nitzan et al., 2002). Tenderness is the most appreciated ostrich meat characteristic. This is due to its low levels of saturated fat and its collagen to protein ratio, which are part of the connective tissue, and are responsible for meat texture, making it easy to digest and to chew. In addition to the low collagen level $(0.44 \%$ in average), the arrangement of the muscle fibers, which are transversally oriented, may also explain its tenderness (Balog et al., 2006).

The characteristic red color of ostrich meat can be explained by its high pigment content $(22 \mathrm{mg} \mathrm{Fe} / \mathrm{g})$. Pigment content varies among different ostrich muscles, with Flexor cruris lateralis, Iliofibularis, and Iliotibialis cranialis presenting more intense color. Meat color is also influenced by water holding capacity, as higher water content results in higher absorption of radiation and lower reflection, making the meat darker (Balog and Almeida, 2007). This study was carried out to assess the quality of ostrich meats produced in Nepal which were of different ages and stored in chilled and frozen conditions

\section{MATERIALS AND METHODS}

\section{Meat sample collection and processing}

Meat samples from two differently aged, 10- and 14-months' ostriches were collected from outlet of Gangoliya Rupandehi by maintaining cold chain. Ice box and ice packs were used for cold chain maintenance and the temperature was in the range of $2-3^{\circ} \mathrm{C}$. Collected samples were divided into three parts for each type. One part was analyzed immediately. Among the remaining two parts, samples were divided equally, packed in polyethylene pouches (thickness 40 microns) and sealed. Thereafter, one part was put in chilling at $4^{\circ} \mathrm{C}$ for 72 hours and next part was put in deep fridge at $-20^{\circ} \mathrm{C}$ for 30 days prior to analyses. Proximate analysis Moisture, protein, fat, total ash, and crude fat as ether extract of ostrich meats of two different treatments were analyzed as per the method mentioned in Meat Science by Lawry (1998). The carbohydrate contents and crude fiber contents in ostrich meat were assumed to be zero. 


\section{RESULTS AND DISCUSSION}

Proximate constituents such as moisture, protein, fat, total ash, and total fat as ether extract of ostrich meats of two different treatments were analyzed results were interpreted on Table 1. The carbohydrate contents and crude fiber contents in ostrich meat were assumed to be zero. Observations were taken at fresh meat, chilled and frozen meats after 72 hours.

Table 1: Proximate analysis of ostrich meat of different treatments

\begin{tabular}{|l|l|l|l|l|l|}
\hline Treatments & $\begin{array}{l}\text { Moisture } \\
\%\end{array}$ & $\begin{array}{l}\text { Protein } \\
\%\end{array}$ & $\begin{array}{l}\text { Total fat } \\
\%\end{array}$ & $\begin{array}{l}\text { Total ash } \\
\%\end{array}$ & \\
\hline T1 (Fresh 14 months' ostrich meat) & $73.98^{\mathrm{ae}}$ & $22.46^{\mathrm{a}}$ & $2.43^{\mathrm{a}}$ & $1.82^{\mathrm{a}}$ \\
\hline T2 (Chilled 14 months' ostrich meat) & $72.86^{\mathrm{b}}$ & $22.98^{\mathrm{ab}}$ & $2.51^{\mathrm{a}}$ & $1.56^{\mathrm{a}}$ \\
\hline T3 (Frozen 14 months' ostrich meat) & $71.67^{\mathrm{c}}$ & $23.35^{\mathrm{b}}$ & $3.03^{\mathrm{b}}$ & $1.24^{\mathrm{b}}$ \\
\hline T4 (Fresh 10 months' ostrich meat) & $75.22^{\mathrm{d}}$ & $21.08^{\mathrm{c}}$ & $2.85^{\mathrm{c}}$ & $1.32^{\mathrm{b}}$ \\
\hline T5 (Chilled 10 months' ostrich meat) & $74.38^{\mathrm{e}}$ & $21.77^{\mathrm{cd}}$ & $3.02^{\mathrm{b}}$ & $1.02^{\mathrm{c}}$ \\
\hline T6 (Frozen 10 months' ostrich meat) & $73.54^{\mathrm{a}}$ & $22.18^{\mathrm{d}}$ & $3.27^{\mathrm{d}}$ & $0.83^{\mathrm{d}}$ \\
\hline F. Pr. & $\mathrm{p}<0.05$ & $\mathrm{p}<0.05$ & $\mathrm{p}<0.05$ & $\mathrm{p}<0.05$ \\
LSD & 0.615 & 0.845 & 0.221 & 0.276 \\
SEM & 0.205 & 0.188 & 0.067 & 0.085 \\
CV\% & 1.5 & 0.9 & 4.4 & 7.8 \\
\hline
\end{tabular}

Values are the means of triplicate analyses. The different superscripts on each mean value in same column indicates significantly different.

Moisture content of older and younger ostrich fleshes were found $73.98 \%$ and $75.22 \%$ respectively at fresh condition. There was subsequent decrement in moisture at cold storage practices. At 72 hours of chilling moisture of older ostrich flesh was reduced almost one percent whereas at frozen condition for one month, moisture was reduced by $2.3 \%$. Moisture contents of ostrich were significantly different at both conditions such as age and storage practices $(p<0.05)$ (Table 1$)$. In case of younger ostrich flesh, the moisture loss was found in similar pattern as older ostrich flesh. The noticeable loss in moisture might be due to the drip loss at chilling condition. Unlikely chilling condition, the loss in moisture at frozen conditions might be the sublimation of exudates at the time of thawing.

The results in this study were very comparable to the findings of Naseva et al., (2010). In his study, ostrich meat contains $74.52 \%$ water. He also mentioned that the values were very similar to chicken flesh $75.58 \%$ and beef flesh $74.21 \%$. The 
protein amounts $22.62 \%$ in the ostrich meat, $17.57 \%$ in the chicken and $21.22 \%$ in the beef; the fats quantity is $0.34 \%$ in the ostrich meat, $5.2 \%$ in the chicken and 1.9 $\%$ in the beef, and the minerals take $1.2 \%$ of the ostrich meat, $0.9 \%$ of the chicken and $1.1 \%$ of the beef.

Regarding protein content, ostrich flesh was found a bit higher protein compare to other meat animal fleshes. The range of protein was 21.08 in younger bird of 10 months to $22.46 \%$ in older bird of 14 months. The amount of protein was found a bit increasing at chilling and more at freezing conditions. However, within the same origin of flesh, there were no significant differences in protein contents at both cold storage practices $(\mathrm{p}<0.05)$ (Table 1$)$. The condition might be due to the loss of water as drip loss at chilling condition and by sublimation at freezing condition and thereby increased solid contents.

In one of the studies by Nitzan et al., 2002, protein level in ostrich meat was assessed about $28 \%$ in average, and the most frequent amino acid is creatine. Protein contents in this study were found lower than the abovementioned study but found similar to the results of Naseva et al., (2010). The major factor might be the environmental condition where ostrich was reared or and the minor one might be the analytical errors.

Total Fat, extracted as ether extract, contents in ostrich fleshes were found significantly different within the age as well as storage practices $(\mathrm{P}<0.05)$ and ranged 2.43 to $3.27 \%$ (table 4.1). Total fat includes fat from residual adipose tissues and intramuscular fats. Fat contributes in palatability of meat and considered eating quality. In this study, difference was insignificant in fat contents between normal and chilled flesh from 14 months' ostrich, but it was statistically different within the meats from younger ostrich.

Fat contents estimated in this study were found higher compare to the study made by Naseva et al., (2010), which was less than $1 \%$. The condition might be due to the error in sampling such as from different anatomical cut up parts or higher content of adipose tissue in the flesh. However, Cooper et al., 2009 also mentioned that fresh ostrich meat contained 0.56 to $3.57 \%$ total fat. Similarly, Paleari et al., (1998) reported that the percentage of fat is the lower for ostrich meat (1.6\%) compared with turkey and bovine, with values of 3.8 and $4.5 \%$, respectively and the results were very comparable to the current study. The fat-to-protein ratio is the key characteristic that favors ostrich meat as a healthy red meat. This ratio was low in ostrich meat (0.07) as compared with turkey and bovine, 0.18 and 0.22 , respectively (Paleari et al., 1998).

Total ash is the combination of all minerals available in the sample. Meat contains 
$1-2.5 \%$ total minerals (Subba, 2010). In this study the range of total ash was 0.83 to $1.82 \%$. The study conducted by Naseva et al., (2010) stated that there were about $1.2 \%$ total minerals in ostrich meat which were similar to chicken flesh $(0.9 \%)$ as well as to beef $(1.1 \%)$. However, value of total minerals was a bit higher in the present study. Results from the current study were statistically different to each other except fresh and chilled meats from 14 months old ostrich $(\mathrm{p}<0.05)$ (Table 1). Total minerals were in decreasing trend in case of chilling and freezing conditions because of the loss of minerals in exudates during chilling or thawing process. Among the ash contents, minerals such as phosphorus, manganese, and iron are higher, and sodium is lower in ostrich meat than either beef or chicken.

\section{CONCLUSION}

This study was conducted first time in Nepal to study on Proximate Analysis of ostrich meat to assess the quality in chilled and frozen condition. This study revealed the carbohydrate contents and crude fiber contents in ostrich meat were assumed to be zero. Observations were taken at fresh meat, chilled and frozen meats after 72 hours

\section{ACKNOWLEDGEMENT}

The authors would like to thanks to extremely grateful to Dr. Binayak P. Rajbhandari (Executive Director and Program Director of Master degree program of HICAST), Dr. Krishna Bahadur Shrestha, Principle and Dr. Upendra Man Singh Program Head of Veterinary Department (HICAST), laboratory staff of HICAST; and also thanks to meat industries of Rupendehi.

\section{REFERENCES}

Annonymous (1992) Meat and meat products for Human Nutrition in Developing Countries. FAO Food \& Nutrition Paper 53, FAO Rome.

Balog, A. and Almeida P. (2007) Ostrich (Struthiocamellus) carcass yield and meat quality parameters.Rev. Bras. Cienc.Avic. 9(4).

Cooper, R. G, Jimenez S, Barbera T, Sendra R, Alvarez P(2006). Quality characteristics of ostrich (Struthiocamelus) burgers. Meat Sci.73: 295-303.

Cooper, R. G. (1999) Ostrich meat, an important product of the ostrich industry: A Southern African perspective. World's Poult. Sci. J. 55: 389-402.

Hoffman, L. C., Fisher P (2001) Comparison of meat quality characteristics between young and old ostriches. Meat Sci. 59: 335-337.

Honikel, K.O. (1987) The water binding of meat. Fleischwirtschaft 67(9), 1098- 
Nepalese Vet. J. 35:71-76

1102.

Horbañczuk, Sales J., Celeda T., Konecka A., Zieba G., Kawka P (1998) Cholesterol content and fatty acid composition of ostrich meat as influenced by subspecies, Meat Sci. 50: 385-388.

Sales J. (1998). Fatty acid composition and cholesterol content of different ostrich muscles. Meat Sci. 49: 489-492.

Sales J., Hayes J. P (1996). Proximate, amino acid and mineral composition of ostrich meat. Food Chem. 56: 167-170. 